\title{
植物器官のデジタル画像面積を効率的に計測できる領域抽出ソフトウエアの開発
}

\author{
七夕高也 ${ }^{1} \cdot$ 山田哲也 ${ }^{2 *} \cdot$ 清水悠介 $^{2} \cdot$ 篠崎良仁 $^{2} \cdot$ 金勝一樹 $^{2} \cdot$ 高野 $\quad$ 誠 ${ }^{1}$ \\ 1 農業生物資源研究所 305-8602 茨城県つくば市観音台 \\ 2 東京農工大学農学部 183-8509 東京都府中市幸町
}

\section{Development of Automatic Segmentation Software for Efficient Measurement of Area on the Digital Images of Plant Organs}

\author{
Takanari Tanabata $^{1}$, Tetsuya Yamada ${ }^{2 *}$, Yusuke Shimizu ${ }^{2}$, \\ Yoshihito Shinozaki ${ }^{2}$, Motoki Kanekatsu ${ }^{2}$ and Makoto Takano ${ }^{1}$ \\ ${ }^{I}$ National Institute of Agrobiological Sciences, Tsukuba, Ibaraki 305-8602 \\ ${ }^{2}$ Faculty of Agriculture, Tokyo University of Agriculture and Technology, Fuchu, Tokyo 183-8509
}

\begin{abstract}
We developed automatic segmentation software for efficient measurement of area on digital images of plant organs. This software enables to measure area size of plant organs from a large number of images with less effort. The developed software has following two features. (1) We developed the technique for dividing plant organs and background using color difference of digital images. An accurate region extraction of plant organs can be executed compared with a conventional binarization method. (2) We developed software functions automating repetitive tasks to improve the task efficiency of image analysis. The developed functions enable efficient software operations and the processing of large number of image analysis. We applied the developed software to analysis of differences in the senescent pattern of petals in Ipomoea nil (L.) Roth. We found that the software effectively detected differences compared with conventional visual comparison methods. The developed software is available for use free of charge by downloading at http://www.kazusa.or.jp/picasos/.
\end{abstract}

Key Words : area measurement, image analysis, petal senescence, phenotypic analysis, varietal differences キーワード : 画像解析, 花弁老化, 系統間差異, 表現型解析, 面積計測

\section{緒 言}

植物の研究では, 植物体の形状を計測して得た值が重要 な情報となる，特に，園芸学の分野では，収穫対象となる 葉や果実，花などの器官について，その形状を評価するこ とが多い。そのため，ノギスなどの測定器具を使用して長 さなどを直接的に計測する方法（梶浦ら，2002）や，ビデ 才画像から重心座標などを間接的に計測する方法（田附・ 塩, 2007）などが提案されている. しかし, QTL 解析や遺 伝資源の特徵付けなどのように, 植物器官の形状を大規模 に評価しなければならない場合，より効率的に形状を計測 できる新たな方法を開発する必要がある。

近年, デジタル画像処理技術を活用し, 植物器官の形状を 計測する新たな方法が提案された（Bylesjöら，2008）。こ の方法を用いれば, コンピュータ処理により大量の画像を自

2009 年 10 月 17 日 受付. 2010 年 2 月 18 日 受理.

本研究の一部は, 農林水産省 新農業展開ゲノムプロジェクト （NVR-0006）の委託を受けて実施した。

本報告の一部は, 園芸学会平成 21 年度秋季大会において発表した.

* Corresponding author. E-mail: teyamada@cc.tuat.ac.jp
動処理することができ, 植物器官の形状を大規模に評価する ことが可能になる。 しかし，そのような大規模化の実現に は，画像処理に用いる “領域抽出法”などのソフトゥエア技 術を改良し，形状計測の効率化を図らなければならない，

領域抽出とは，デジタル画像中の被写体など特定の対象 物について，その画像領域を選択し，背景との区別を行う 操作のことである. 画像処理により植物器官の形状を計測 する場合，この領域抽出を最初に行い，画像中の器官と背 景とを区別する必要がある。領域抽出には “2 值化法”と 呼ばれる手法が主に用いられている。２值化とは，画像中 の抽出対象と背景を, それらの領域の色や輝度值の違いに 基づき区別する操作のことであり，Adobe ${ }^{\circledR}$ Photoshop $^{\circledR}$ ( ドビシステムズ）や ImageJ（フリーソフト，http://rsb.info, nih.gov/ij/) など汎用の画像解析ソフトゥエアを用いて実行 することができる。

2 值化法により領域抽出を行らためには, 抽出対象と背 景の色拈よび輝度值が大きく異なるデジタル画像を用いる ことが重要となる，植物でも，青や赤など単色の幕を背景 として撮影した画像（田附・塩，2007; 山本，2003） やス キャナで取り込んだ画像（Bylesjöら，2008; Weight, 2008) 
を用いた領域抽出が行われている。しかし，固場などで撮 影した背景が単色でない画像や暗い照明下で撮影したコン トラストの低い画像なぞを用いる場合，2 值化のための閾 值の微調整なぞ, 極めて煩雑な操作が要求される. また, それでも 2 值化に失敗した場合, 修正作業が必要となるた め，大量の画像を自動処理することは困難となる。

そのような 2 值化法に打ける問題の解決には, デジタル 画像の色情報に基づいて領域抽出を行ら方法（山本，2003） が有効と考兄られる. この方法では, 植物体の色とそれに 近い背景の色を判別することができるため, 通常の 2 值化 法よりも正確に領域抽出を行らことが可能である. しかし， 戋場で撮影した画像のように複数の色が背景に混在する場 合, 色の判別に多くの時間がかかり, 領域抽出の効率が低 下してしまう。そのため, 大量の画像を自動処理するため には, 色の判別をより迅速に行うことのできる新たな領域 抽出法を考案する必要がある。

領域抽出後のデジタル画像からは, 特定の画像領域にお ける距離, 面積および重心座標などの測定情報が得られる. それらの情報は, 成長や老化に伴ら植物器官の形状変化を 客観的に評価する指標として用いることができる. しかし， そのような評価を行うためには，対象となる植物器官の時 系列画像を大量に解析しなければならない。 また，植物器 官の形状を大規模に評価する場合にも，大量の画像を解析 する必要がある. そのため, 領域抽出とその後の距離や面 積などの測定を連続的に実行できる新たなりフトウエアの 開発が求められている.

そこで，本研究では，デジタル画像処理技術を活用した 植物器官の形状計測を効率化するため, 色情報 (平均色差) を使った新たな領域抽出法を考案するとともに，その手法 による領域抽出とその後の面積計測を複数の画像に対して 連続的に実行できるッフトゥェアを開発した，さらに，そ のソフトウエアを用い，2 種類のアサガオ自殖系統につい $\tau$, 花冠の時系列画像を解析し, 得られた花冠面積の時系 列データから花弁老化の系統間差異を検出することで，開 発した領域抽出ソフトゥエアの実用性を確認した.

\section{材料および方法}

\section{1. 領域抽出法の考案 (実験 1)}

第 1 図 A に，アサガオ（Ipomoea nil（L.）Roth）の花冠 (赤色), 花を挿したプラスチックチューブを固定するチュー ブスタンド (白色) およびそのスタンドを置いた実験台（黒 色）をデジタルカメラで撮影した画像（解析対象画像）を 示す. この画像を利用し, 植物器官の画像領域を抽出する 方法を考案した．領域抽出を行う前に，まずは，解析対象 画像中の花冠 $(S 1)$, チューブスタンド $(S 2)$ 打よび実験台 （S3）の一部を参照画像として定義した（第 1 図 B)，参照 画像はサイズが大きく, 数が多いほど正確に領域抽出を行 光るが，抽出にかかる時間は増兄てしまう。本実験では， 試行錯誤により，参照画像のサイズを 16 ピクセル × 16 ピ

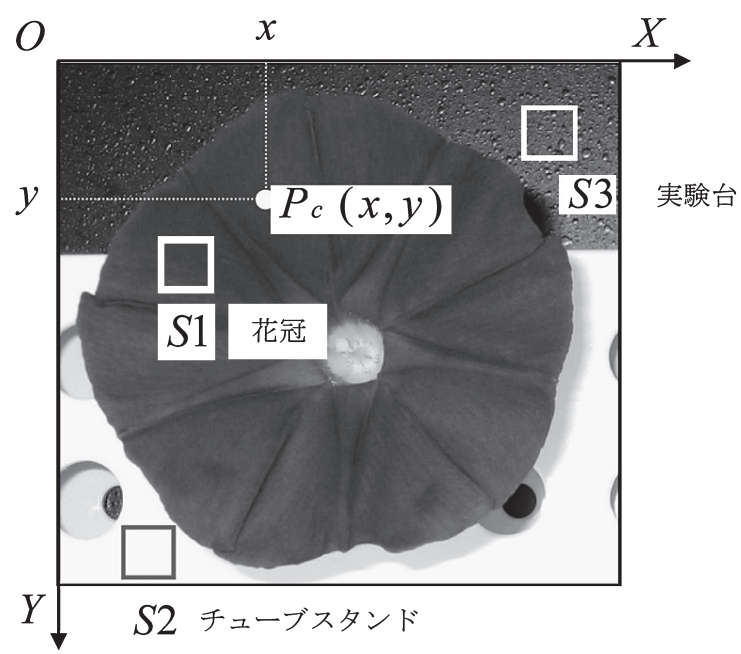

A. 解析対象画像

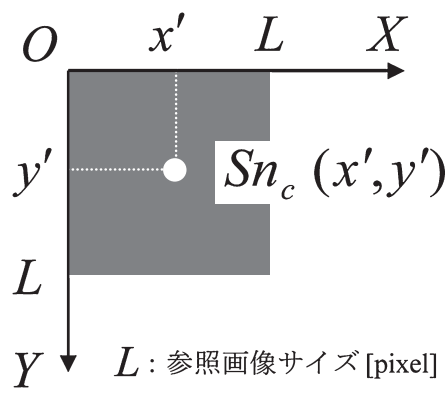

B. 参照画像

第 1 図 解析対象画像と参照画像

クセル，数を $2 \sim 3$ 枚とした. 領域抽出は，数式 (1) で求 めた解析対象画像中の点 $P$ と参照画像との平均色差 $(\Delta P n)$ を使って行った。

$$
\begin{aligned}
& \Delta P n=\frac{1}{L \times L} \sum_{x^{\prime}=0}^{L} \sum_{y^{\prime}=0}^{L} \delta n^{P}\left(x^{\prime}, y^{\prime}\right) \quad(n=1,2, \ldots) \\
& \delta n^{P}\left(x^{\prime}, y^{\prime}\right)=\sqrt{\sum_{c=L, a, b}\left(P_{c}(x, y)-S n_{c}\left(x^{\prime}, y^{\prime}\right)\right)^{2}}
\end{aligned}
$$

平均色差の算出には CIE-L*a*b 表色系の $\mathrm{L}^{*} \mathrm{a} * \mathrm{~b} *$ 值を用い た. 第 2 図に, 平均色差を使って植物器官（花冠）の領域 抽出を実行する際に用いた自動抽出処理のアルゴリズムを 示す.はじめに，撮影画像の粒状ノイズを除去するため, 画像全体にメディアンフィルタを適用した．次に，解析対 象画像の点 $P$ に扔ける画素の RGB 值から $\mathrm{L}^{*} \mathrm{a}^{*} \mathrm{~b}$ *值を求め た. さらに, すべての参照画像 $(S 1 \sim S 3)$ について点 $P$ と の平均色差を求め, 一番小さな值を示す参照画像 $\left(S_{\min }\right)$ を 決定した. $S_{\text {min }}$ が $S 1$ の場合には “花冠” と判定して 255 を, $S 2$ または $S 3$ の場合には “背景” と判定して 0 を点 $P$ の値 とした．この作業を解析対象画像中のすべての点について 実行することで，花冠領域を抽出した 2 值化画像を得た. 最後に, 判定ミスにより発生した 2 值化画像中の粒状ノィ 


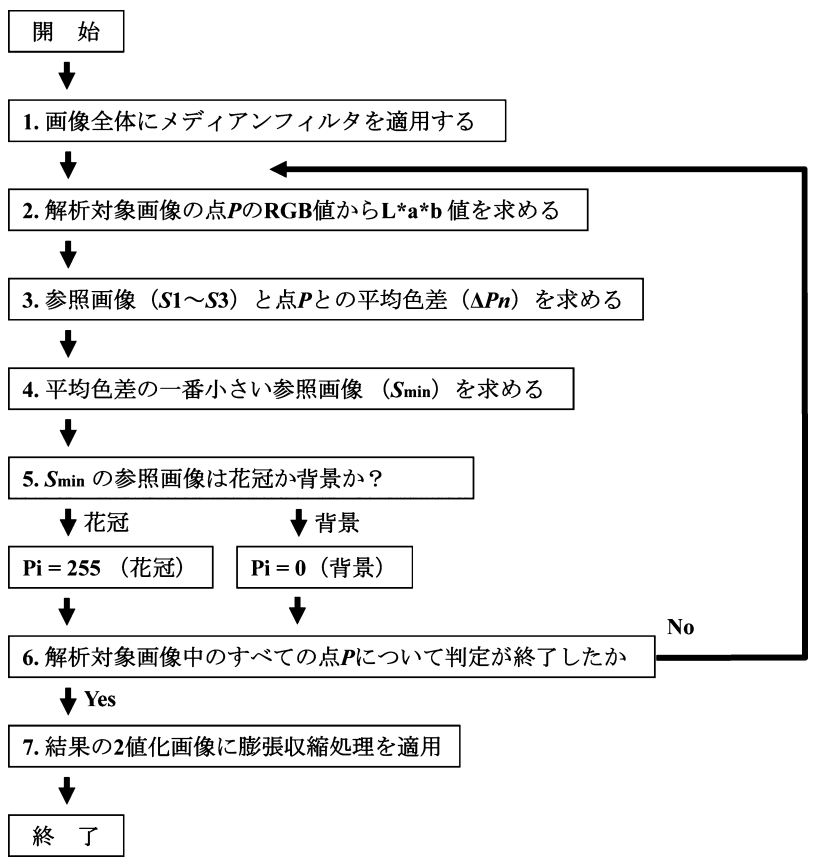

第 2 図自動抽出処理のアルゴリズム

ズを除去するため，膨張収縮処理を適用した．

\section{2. 領域抽出ソフトウエアの開発（実験 2）}

実験 1 で考案した領域抽出法を使い，複数の画像に対し て連続的に領域抽出を行うとともに，抽出した画像領域の 面積を計測できるソフトウエアを開発した。ソフトウェア の開発にはVisualC++ (Microsoft ${ }^{\circledR}$ Visual Studio 2005) と OpenCV（Intel ${ }^{\mathbb{R})}$ を使用した。第 3 図に，開発したソフト ウエアの実行画面と解析結果の出力形式を示す。このソフ トゥエアは，任意のフォルダに保存されたデジタル画像を 順番に読み込久，領域抽出と面積計測を実行し，フォルダ 中のすべての画像を解析した後, その結果をまとめて出力 する機能を持つ. 第 4 図に, 開発したりフトウエアの解析 手順を示す。ソフトウェアを起動した後, 解析したい画像 が保存されたフォルダを指定すると, フォルダ内の画像 ファイル（Bitmap, Jpeg, Tiff）が検索され，ファイルの名前 順に並べられた画像リストが作成される．このリストの順 番に従って画像が 1 枚ずつ実行画面に表示されるので，そ の画像について植物器官と背景の参照画像をそれぞれ 1 枚 以上指定する. 解析対象領域を指定して自動抽出処理を実 行すると, 植物器官の領域抽出が行われ, その結果が実行 画面に表示される。 このとき，間違って抽出された場所が あれば，2 值化画像を使って修正することができる．最後 に, 抽出された領域のピクセル数を求め, 植物器官の画像 面積を計測する。フォルダ内のすべての画像について解析 が終わると, 解析結果が CSV 形式のファイルにまとめて出 力される。な拈，開発したりフトウェアは “Flower Shape Analysis System” と命名し, http://www.kazusa.or.jp/picasos/ でフリーウェアとして公開している.

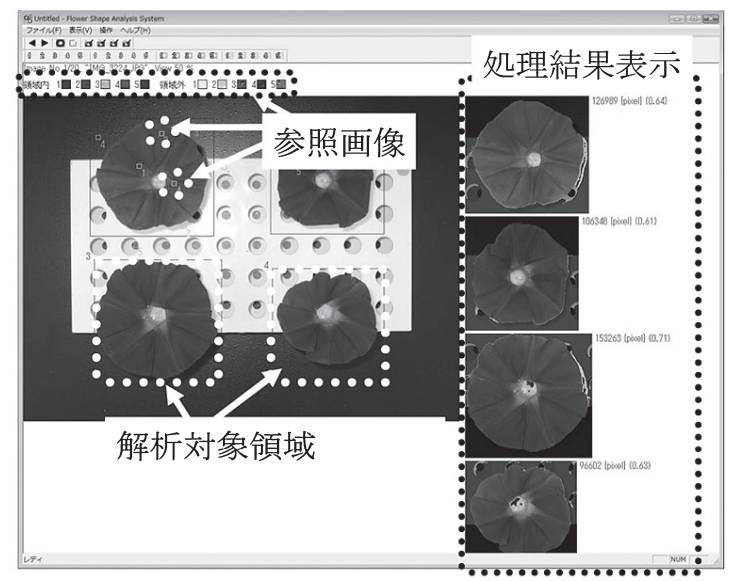

A. 実行画面

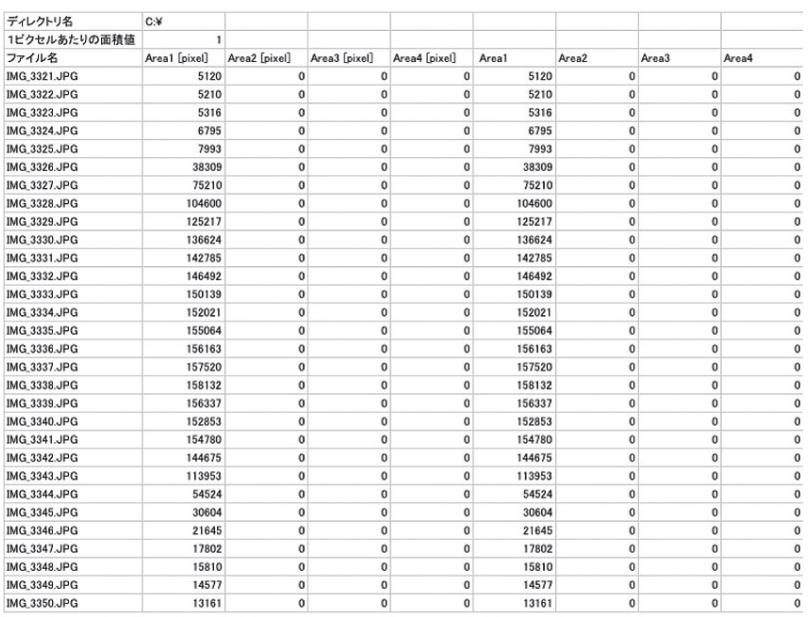

B. 出力形式

第 3 図 開発したソフトゥエアの実行画面と解析結果の出力 形式

\section{3. 開発したソフトウェアの実用性の確認（実験 3）}

アサガオの自殖系統 ‘紫” と “渦” の実生を $25^{\circ} \mathrm{C}, 12$ 時 間日長（12:00〜24:00）飞設定したインキュベータ一内で 栽培し，実験に供試した。開花当日 10:30〜11:00 の間に, 各系統の実生から花弁の展開を開始している花を, 墓下 0.5 $\sim 1 \mathrm{~cm}$ の花柄を残して切除した. 採取した花の花柄を, 蒸 留水を注水した $2 \mathrm{~mL}$ 容量のポリプロピレン製マイクロ チューブ（直径 $10 \mathrm{~mm}$, 長さ $40 \mathrm{~mm}$ ) に挿し, インキュ ベーター内に静置した。インターバル撮影機能を備えたデ ジタルカメラ（PowerShot S3 IS，キャノン）を用い，天井 側から 30 分ごとに花の様子を撮影し,花冠の時系列画像を 得た。画像データを PC に取り込み，モニタ一上で各系統 の画像を時系列に並べ，花冠形状の変化について視覚的な 比較を行った. 次に, 実験2で開発したりフトウェア (Flower Shape Analysis System）を用い，花冠の時系列画像を解析し た．画像中の各花について花冠の領域抽出を行い，その領 域の面積を計測することで，花冠面積の時系列データを得 た．各花の花冠面積の時系列データについて，その最大值 


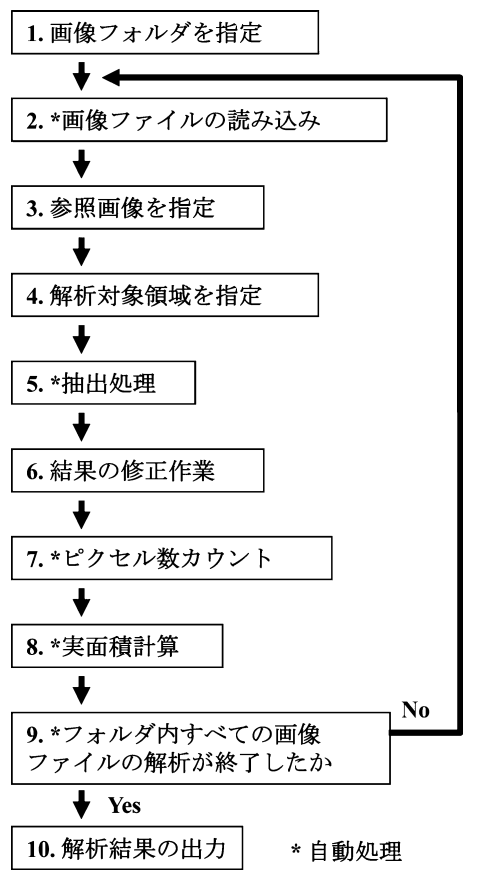

第 4 図 解析手順

を 100 とした時の相対值を求め, これを花冠面積の变化を 評価する指標とした. さらに, 各花の花冠面積の相対值が 90 以上に到達した状態を“開花”，その後，90 以下に到達 した状態を“インローリング（花冠の周縁部が老化に伴っ て萎縮し, 向軸側に巻き込まれる状態)” と定義し, 開花後 インローリングが開始するまでの時間（h）を求め，これを 花弁老化が開始する時期を評価する指標とした.

\section{結果および考察}

\section{1. 領域抽出法の考案（実験 1)}

本実験で考案した領域抽出法の性能を評価するため, 実 験室内で撮影したアサガオ花冠のデジタル画像に対して抽 出処理を試み, 他の領域抽出法と結果を比較した(第 5 図). な拝，解析対象は，アサガオの花が開花してから萎れるま での花冠形状の変化を解析することを目的として得た時系 列画像の一枚であり，第 1 図に示したものと同じ画像であ る (第 5 図 A)。この原画像に対し, Adobe ${ }^{\circledR}$ Photoshop ${ }^{\circledR}$ を 用いた 2 值化処理（閾値 140）による領域抽出を行ったと ころ，花冠だけでなく，実験台やチューブスタンドの影も 同時に抽出された（第 5 図 B)。一方，考案手法では，花冠 だけが抽出されることを確認した（第 5 図 C)。このよう に，色情報を使った考案手法では，背景に異なる色が混在 した画像でも，正確な抽出処理が可能であることを明らか にした.

色情報を使った他の領域抽出法と比較するため, フリー ウェア “LIA32”（山本，2003）による抽出を試及た. LIA32 には，任意に指定した画像中の座標と同じ色を示す領域を 抽出する色探索機能がある。この機能を使って抽出を行っ
A

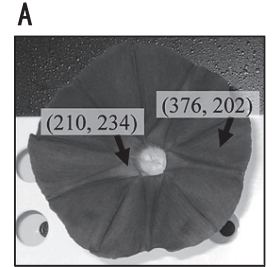

B

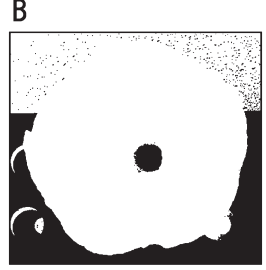

C

D

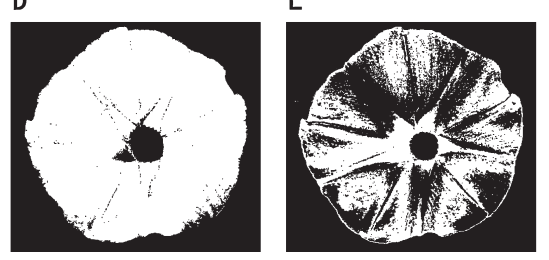

第 5 図 実験室内で撮影したアサガオ花冠の画像に対する抽 出処理結果

$\mathrm{A}$ : 抽出処理に用いた原画像，括弧内の数値は色情報を 得た画像中の座標を示す, B : Adobe ${ }^{\circledR}$ Photoshop $^{\circledR}$ による 2 值化処理（閾值 140）による抽出，C：提案手法によ る抽出, D : LIA32 による座標 $(376,202)$ の色情報（R169, G50, B144）を用いた抽出，E：座標（210, 234）の色情 報（R220, G74, B111）を用いた抽出

たところ，指定した座標の違いにより，良好な結果が得ら れる場合（第 5 図 D）と，そうでない場合（第 5 図 E）が あることを確認した. LIA32 の色探索機能には，色の違い を許容する範囲を設定できるオプションがあり，その設定 を画像ごとに厳密に行えば，より正確な抽出が可能になる と思われる。しかし，そのための試行錯誤の時間を考劣る と，考案手法の䚾らが処理効率は良いと判断された。

被写体や背景に複数の色が混在する複雑な画像に対する 考案手法の性能を評価するため, 圃場で撮影したアカク ローバーの画像に対して抽出処理を試みた（第 6 図）。原画 像に対し，Adobe ${ }^{\circledR}$ Photoshop ${ }^{\circledR}$ を用いて 2 值化処理（閾值 140）を行ったところ，被写体に影がかかっている部分（a） や被写体の輪郭が明確でない部分（b)，複雑な色合いを示 す背景の部分（c）では，正確な抽出が行われなかった（第 6 図 B). 一方，考案手法では，そのような部分でも比較的 正確に抽出が行われて扣り（第 6 図 C), 複雑な画像でも, 若干の修正を加えれば，十分に領域抽出を行えることが示 された。

考案手法は, あらかじめ指定した植物器官と背景のサン プル（参照画像）を使い，解析対象画像の各画素が植物器 官と背景のどちらにより近い色を示すかを判別する方法で ある。また，抽出する領域だけでなく，抽出しない領域の 色情報を使うことで，判別の正確性を高めている，考案手 法の主な特徵を挙げると，次の 3 つになる.

\section{1）簡易な解析作業の実現}

画像処理を実行するために必要な設定は，植物器官（抽 出する領域）と背景（抽出しない領域）の指定だけで，作 業を繁雑にする数值パラメータの調整や画像処理の知識は 不要である. 


\section{2）照明変化に強い}

色情報を使った判定であり，通常の 2 值化法で行われる 輝度情報による処理では失敗するよらな画像でも, 抽出処 理を実行できる，撮影のたびに照明の強さが変わり，画像 が明るい, 暗いと変化するよらな場合にも, 安定して抽出 処理を実行できる.

\section{3）複数色の植物器官や背景への対応}

固場で撮影した背景の色が複雑な画像から植物器官を抽 出する場合や，花と葉のように異なる色の植物器官をまと めて抽出する場合でも, 参照画像を複数用意することで一 度に処理することができる。

c

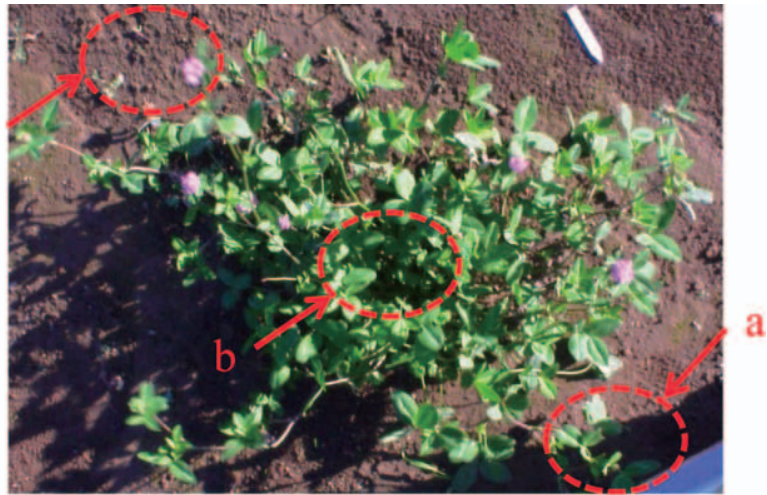

A. 原画像

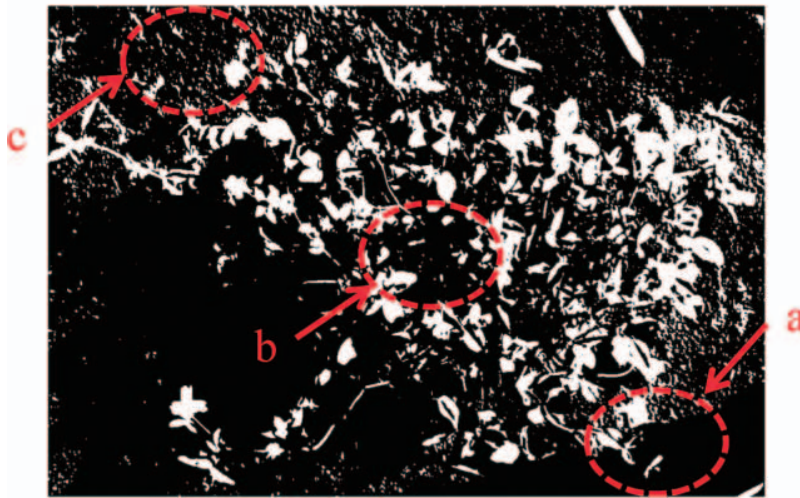

B. 2值化処理の結果（闘値140）

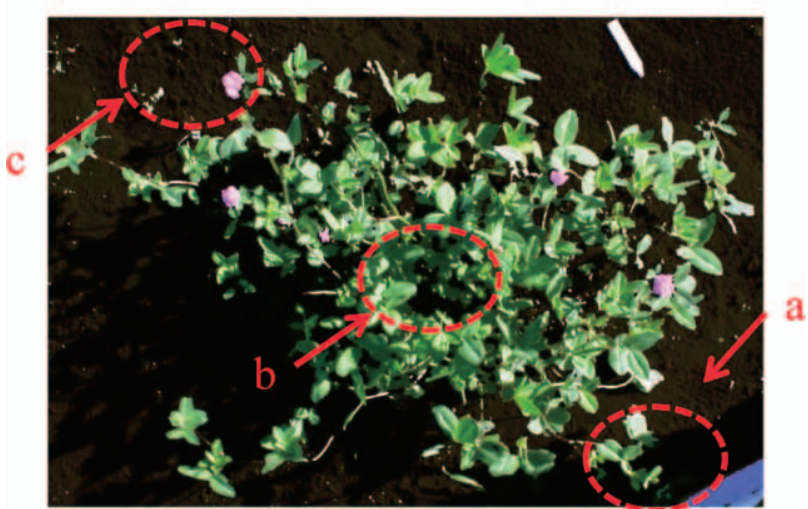

C. 考案手法で処理した結果

第 6 図 固場で撮影したアカクローバーの画像に対する抽出 処理結果
2. 領域抽出ソフトウェアの開発（実験 2）

本実験で開発した領域抽出ソフトウエア（Flower Shape Analysis System）の作業効率について考察する. デジタル 画像処理技術を活用し，植物器官の形状変化を評価するた めには, 大量の時系列画像に対して植物器官の領域抽出と 面積計測を行ら必要があるが, それらを Adobe ${ }^{\circledR}$ Photoshop $^{\circledR}$ や ImageJを使用して実施する場合,

(1) 画像ファイルを選択して開く

(2) 領域抽出処理（2 值化，色範囲指定）を実行する

(3) 抽出した領域のピクセル数を計測する

(4) 計測したデータをメモする

(5) 画像ファイルを閉じる

A
紫

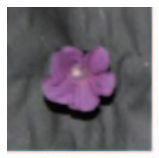

渦

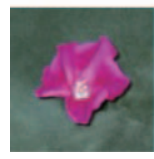

$0 \mathrm{~h}$
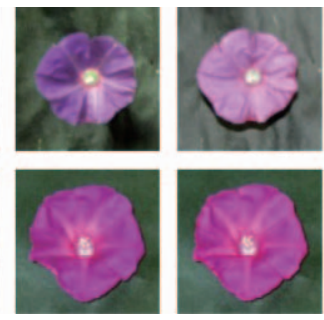

$4 \mathrm{~h}$

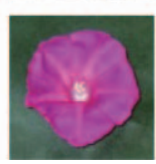

$8 \mathrm{~h}$
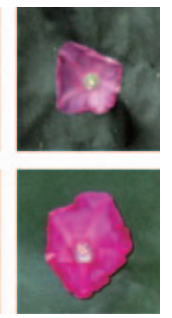

$12 \mathrm{~h}$
B

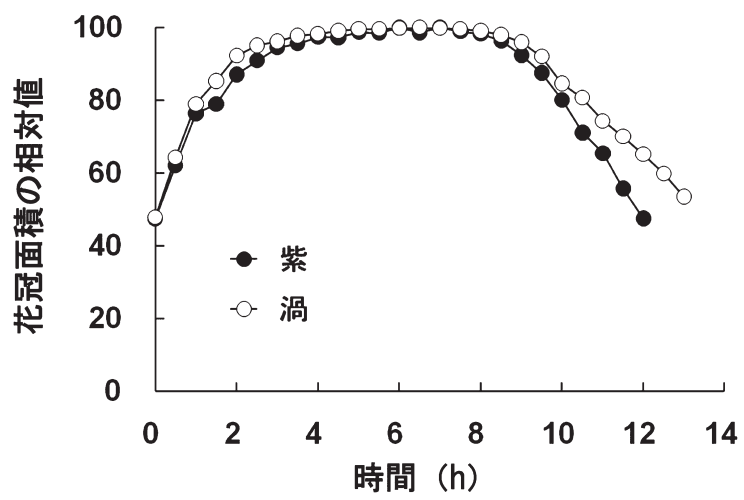

C

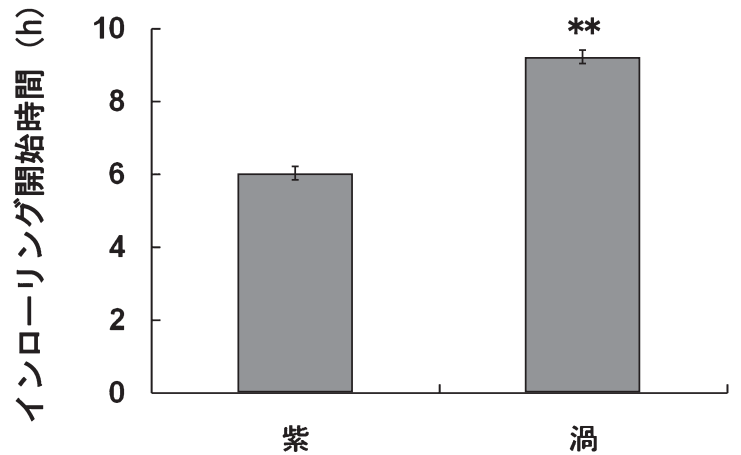

第 7 図 時系列画像の解析によるアサガオの花弁老化に関す る系統間差異の検出

A : 花冠形状の変化を視覚的に比較した結果, B : 花冠 面積の変化を相対値で比較した結果, C : 花弁老化の開 始時期をインローリング開始時間で比較した結果, 垂直 線は標準䛊差（n=5）を示す，**は $\mathrm{t}$ 検定により $1 \%$ 水 準で有意差あり 
(6) 画像枚数分(1)一(5)を繰り返す

(7)メモしたデータを表計算ソフトに入力する といら手順で操作が進められる。 このらち, (4)と(7)の操作 は，作業者への負担が非常に大きく，計測データの記録ミ スや転記ミスが生じる可能性がある。また，(1)の操作も， 大量の画像を処理する場合, 画像ファイルの選択ミスが生 じる可能性がある。一方, Flower Shape Analysis System を 使用寸る場合，

(1)，画像ファイルが入っているフォルダを指定する

(2) , 解析対象領域を指定する

(3) 参照画像を指定する

(4), 領域抽出処理の実行する

(5), 画像枚数分(2) 一-(4), 繰り返す

(6)，計測結果ファイルを出力する

といら手順で操作が進められる。 このうち, 作業者に負担 のかかる作業は(2), と(3)' だが, これは画面に示された画像 の一部を指定する簡単な操作であり, 負担の度合いは比較 的小さいと判断される. また, 画像ファイルの選択や計測 データの記録が自動化されているため, 作業負担やミスの 発生が軽減され, Photoshop ${ }^{\circledR} や$ ImageJ を使用する場合に比 べ，作業効率は大幅に改善されている.

\section{3. 開発したソフトゥエアの実用性の確認（実験 3）}

実験 2 で開発した領域抽出ソフトウェアの実用性を確認 するため，アサガオの自殖系統“紫”と“洞”について， 花冠の時系列画像を解析し, 花弁老化に関寸る系統間差異 の検出を試みた（第 7 図）。はじめに, 各系統の時系列画像 を並べて表示し, 花弁老化に伴う花冠形状の変化を視覚的 に比較した（第 7 図 A)。その結果, 花冠形状の変化につい て，2つの系統間に差異があるかどらかを明確に判断する ことは困難であることが分かった。 そこで, Flower Shape Analysis System を用い, 各系統の時系列画像から花冠面積 の時系列データを求め, 花弁老化に伴ら花冠面積の変化を 比較した. 花冠面積の相対值を用い, 採花時 $(0 \mathrm{~h})$ の花弁 の展開程度が泳涪同じ ‘紫” と“渦”の花について比較を 行ったところ（第 7 図B）, 花冠面積は両系統とも採花後 $8 \mathrm{~h}$ 以降に減少するが，その減少速度は“渦”に比べ紫” のほうが早く，2つの系統間には花弁老化の速度について 差異が存在することが示された，さらに，各系統の花冠面 積の時系列データから，開花後インローリングが開始する までの時間を求め, 花弁老化が開始する時期を比較したと ころ（第 7 図 C)，“紫”と“渦’ のインローリング開始時 間には有意な差が認められ，2つの系統間には花弁老化の 開始時期についても差異が存在することが明らかになっ
た. 以上の結果から, 時系列画像の視覚的な比較では器官 形状の変化について差異を確認することが困難な系統間で も, 本研究で開発したりフトウェアを用いて時系列画像を 解析することにより，系統間差異を検出することが可能で あることが示唆された。

\section{摘要}

デジタル画像処理技術を活用した植物器官の形状計測を 効率化するため，色情報（平均色差）を使った新たな領域 抽出法を考案し, その手法による領域抽出とその後の面積 計測を連続的に実行できる領域抽出ソフトウェア “Flower Shape Analysis System” (http://www.kazusa. or.jp/picasos/) を 開発した。従来法との比較から，考案した手法は，被写体 や背景の色が複雑な画像でも, 植物器官の領域抽出を効率 よく，正確に実行できることを明らかにした．また，開発 したソフトウェアは, 画像ファイルの選択や計測データの 記録が自動化され，作業効率が大幅改善されている。さ らに，開発したソフトウェアを用い，アサガオ花冠の時系 列画像を解析したところ，視覚的な比較では検出が困難な 花弁老化の系統間差異を容易に検出することができた．以 上の結果から，本研究で考案した手法拉よび開発したりフ トゥエアが，植物器官の形状計測に極めて有用であること が示唆された。

謝 辞 ソフトウエア評価のための圃場画像を提供いた だいた磯部祥子博士（かずさ DNA 研究所）に深く感謝い たします。

\section{引用文献}

Bylesjö, M., V. Segura, R. Y. Soolanayakanahally, A. M. Rae, J. Trygg, P. Gustafsson, S. Jansson and N. R. Street. 2008. LAMINA: a tool for rapid quantification of leaf size and shape parameters. BMC Plant Biol. 8: 82. DOI: 10.1186/ 1471-2229-8-82. 〈http://www.biomedcentral.com/〉.

梶浦一郎・町田 裕・佐々木 修・大垣智昭. 2002. ナシ 葉形の簡便な数值化法. 園学研. 1:5-8.

田附明夫 - 塩 光輝. 2007. 数種浸透質の添加と無酸素ま たは通気停止処理によるキュウリ幼植物体の水ストレ スの画像診断. 園学研. 6: 367-373.

Weight, C., D. Parnham and R. Waites. 2008. LeafAnalyser: a computational method for rapid and large-scale analyses of leaf shape variation. Plant J. 53: 578-586.

山本一清. 2003. LIA for Win32 (LIA32). フリーウエア. http://www.agr.nagoya-u.ac.jp/\%7Eshinkan/LIA32/ 